\title{
STATE REGULATION OF SOUTH AFRICAN INSOLVENCY LAW AN ADMINISTRATIVE LAW APPROACH*
}

\author{
Juanitta Calitz \\ Biur LLB LLM LLD \\ Senior Lecturer, Department of Mercantile Law \\ University of Johannesburg
}

\section{SUMMARY}

Although the Constitution must inform the way legislation is interpreted by the courts, there is currently no Constitutional Court decision or secondary source which deals directly with the application of the Constitution to state regulation in South African insolvency law. With regard to the role and function of the Master as well as any future state regulation in insolvency law, certainly the most significant development within the context of the Constitution is the enactment of the Promotion of Administrative Justice Act (PAJA) which gives effect to the principles envisaged in section 33 of the Constitution. The aim of this article is not to provide a detailed exposition or comprehensive overview of constitutional and administrative law, but rather to highlight the relevance and potential impact of certain administrative law aspects on the functioning and day-to-day operation of a regulatory institution in South African insolvency law.

\section{$1 \quad$ INTRODUCTION}

"The South African Constitution is different: it ... represents a decisive break from, and a ringing rejection of, that part of the past which is disgracefully racist, authoritarian, insular, and repressive and a vigorous identification of and a commitment to a democratic, universalistic, caring and aspirationally egalitarian ethos, expressly articulated in the Constitution."

In the case of Pharmaceutical Manufacturers Association of South Africa: In re Ex Parte President of the Republic of South Africa ${ }^{2}$ Chaskalson $\mathrm{J}$ confirmed that there is only one system of law in South Africa and that all law, including the common law, derives its force from the Constitution of the

* This article is partially based on Calitz $A$ Reformatory Approach to State Regulation of Insolvency Law in South Africa (LLD thesis, University of Pretoria, 2009). I am grateful to Prof Hennie Strydom for his input and comments. The views expressed in this article remain my own.

S v Makwanyane 1995 (3) SA 391 (CC) par 262.

22000 (2) SA 674 (CC). See Davis "To Defer and then When? Administrative Law and Constitutional Democracy" 2006 Acta Juridica 23. 
Republic of South Africa. ${ }^{3}$ As the supreme law of the land the Constitution has changed the face of our law dramatically in that legislation may now be tested by the courts in order to establish its constitutionality. ${ }^{4}$

The Constitution featuring a Bill of Rights ${ }^{5}$ was not in place when the Insolvency Act $^{6}$ came into force. Consequently, the values and principles entrenched in the Constitution in many instances differ radically from the values, principles and policies that formed the foundation of the Insolvency Act. $^{7}$ The Department of Justice and Constitutional Development is currently in the process of reviewing the South African insolvency legislation as well as the regulation of the insolvency profession. ${ }^{8}$ It is, however, extremely important that any law reform process or any recommendations that are eventually proposed would constitute a more accurate reflection of the current legal, socio-political and economic environment in South Africa and any proposals for future law reform are done within the spirit of the Constitution. $^{9}$

The article commences with a few general remarks on the impact of the Constitution on insolvency law and in particular the regulation of insolvency law as conducted by the Master of the High Court. ${ }^{10}$ The focus then shifts to a brief discussion of certain aspects of administrative law, in particular the Promotion of Administrative Justice $\mathrm{Act}^{11}$ as it relates to the powers and functions of the Master. It must be stated here that the aim of this article is not to provide a detailed exposition or comprehensive overview of constitutional and administrative law, but rather to highlight the relevance

3 Constitution of South Africa, 1996 (hereinafter "the Constitution"). See Hoexter Administrative Law in South Africa (2012) 28.

4 Dlamini "The Right to Administrative Justice in South Africa" 2000 TSAR 697701.

5 The Bill of Rights is set out in Chapter 2 of the Constitution. See generally: Currie and De Waal The Bill of Rights Handbook (2005).

624 of 1936 (hereinafter "the Insolvency Act or Insolvency Act of 1936").

7 See Evans A Critical Analysis of Problem Areas in respect of Assets of Insolvent Estates of Individuals (LLD thesis, University of Pretoria, 2009) 379.

8 Since its core insolvency legislation hails from 1936, the South African Law Reform Commission, has embarked on an extensive study of South African insolvency law and published its Report on the Review of the Law of Insolvency in 2000: see South African Law Commission, Project 63, Commission Paper 582 Review of the Law of Insolvency (2000) Vols 1 and 2. For a more detailed discussion see Evans (LLD, University of Pretoria, 2009) 430; Burdette Framework for Corporate Insolvency Law Reform in South Africa (LLD, University of Pretoria, 2002) Chapter 3; Keay "To Unify or Not to Unify Insolvency Legislation: International Experience and the Latest South African Proposals" 1999 De Jure 62-79; Boraine and Van der Linde "The Draft Insolvency Bill - An Exploration (Part 1)" 1998 TSAR 621; Havenga "Simplification and Unification in Corporate and Insolvency Law - Are We Making Any Progress?" 2001 SA Mercantile LJ 408; and Loubser "An International Perspective on the Regulation of Insolvency Practitioners" 2007 SA Mercantile LJ 123.

9 Davis 2006 Acta Juridica 23.

10 Hereinafter "the Master or Master's office". The Master of the High Court is a public servant who is charged, inter alia, with control over the administration of insolvent estates. S 1 of the Administration of Estates Act 66 of 1965 defines "Master" in relation to any matter, property or estate, as the Master, Deputy Master or Assistant Master of the High Court who has jurisdiction in respect of the matter, property or estate; and see Calitz "The Role of the Master of the High Court as Regulator in a Changing Liquidation Environment: A South African Perspective" 2005 TSAR 728.

113 of 2000 (hereinafter "PAJA"). This Act came into force on 2000-11-30, except ss 4 and 10 which came into force on 2001-07-31. 
and potential impact of these branches of South African law on the functioning and day-to-day operation of a regulatory institution in South African insolvency law.

\section{CONSTITUTIONAL LAW ASPECTS REGARDING STATE REGULATION OF SOUTH AFRICAN INSOLVENCY LAW}

\section{Introduction}

With the recognition of the Constitution as the supreme law of the land, the legal community in South Africa had to adapt from the old concept of parliamentary sovereignty to a new model of constitutional democracy. ${ }^{12}$ In Holomisa $v$ Argus Newspaper $L t d^{13}$ Cameron $J$ (as he then was) summarized this principle very well: "The Constitution has changed the "context' of all legal thought and decision-making in South Africa". ${ }^{14}$ Although the Constitution must inform the way legislation is interpreted by the courts, there is currently no Constitutional Court decision or secondary source which deals directly with the application of the Constitution to state regulation in South African insolvency law. ${ }^{15}$ Despite the lack of a thorough treatment of the subject of the constitutional aspects of the role of the Master in general, it is clear that the law of insolvency cannot possibly escape the reach of the Bill of Rights, given the contentious nature of an insolvency status and the various conflicting interests involved. ${ }^{16}$ The aim and purpose of any state regulation in South African insolvency law should thus be to ensure compliance with the underlying values of the Constitution, which include the protection of societal interests and of individual rights and freedoms.

Law and the Constitution do not exist in a vacuum, but rather exist in society and aim to serve it. ${ }^{17}$ Moreover, given South Africa's past, it is obvious why the Constitution's articulated vision is to protect individuals, and especially vulnerable categories of people, and to safeguard against any

12 Hoexter “'Administrative Action' in the Courts” 2006 Acta Juridica 303.

131996 (6) BCLR 836 (W) 836J.

14 See Botha "Administrative Justice and Interpretation of Statutes: A Practical Guide" in Lange (ed) The Right to Know (2004) 14.

15 Thus far most of the constitutional cases pertaining to South African insolvency law have either dealt with constitutionality in general, or with certain aspects of the legal concept of interrogations within the context of South African insolvency law. See, eg, De Lange v Smuts 1998 (3) SA 785 (CC); Bernstein v Bester NNO 1996 (2) SA 751 (CC); Ferreira v Levin NO 1996 (1) SA 984 (CC). Other insolvency-related aspects which have been subject to judicial scrutiny include s 21 of the Insolvency Act in the case of Harksen $v$ Lane 1998 (1) SA 300 (CC). See also Part Four in Evans (LLD, University of Pretoria, 2009) for a detailed discussion of $\mathrm{s} 21$ of the Insolvency Act.

16 See Calitz "The Appointment of Insolvency Practitioners in South Africa: Time for Change?" 2006 TSAR 721; Burdette Reform, Regulation and Transformation: The Problems and Challenges Facing South African Insolvency Industry (2005) unpublished paper presented at the Commonwealth Law Conference, London (hereinafter "Burdette 'Reform, Regulation and Transformation"'). On file with the author.

17 James "The Judiciary and the Emerging Principle of Interest and Spirit of the Constitution" 2003 Melanesian LJ 29. 
abuse of power by organs of state $^{18}-$ hence the Constitutional emphasis on the establishment of a public administration that is governed by the principles of the Constitution and that is accountable, transparent, impartial and efficient. ${ }^{19}$ For this reason, the inclusion in the Bill of Rights of a right to just administrative action is of great importance.$^{20}$ One practical outcome of this provision is that service to the people has become a guiding principle of the public service in South Africa. ${ }^{21} \mathrm{~A}$ responsive administration is thus one which is alert to the needs of its people and which addresses these needs effectively. ${ }^{22}$

In moving from a culture of authority to a culture of justification and accountability it must be clear that the Constitution, and especially the Bill of Rights, has fundamentally changed the way any state authority or administration is supposed to function. ${ }^{23}$ For instance, it is precisely because of the principle of accountability that the Master is drawn into the discussion on the constitutional aspects of insolvency law. This is particularly so since some of the most important specific provisions flowing from the principle of accountability are part of the Bill of Rights and include, most significantly, the right to access to information in section 32 and the right to just administrative action in section $33 .^{24}$ Both of these provisions are aimed at ensuring transparency and accountability in the public administration, ${ }^{25}$ which are among the main themes of the Constitution and which form an integral part of the constitutional foundation of administrative justice. ${ }^{26}$ With regard to the role and function of the Master as well as any future formation of state regulation in insolvency law, certainly the most significant development within the context of the Constitution is the enactment of PAJA which gives effect to the principles envisaged in section 33 of the Constitution.

18 S 8(1) of the Constitution. The definition of "organ of state" in s 239 in the Constitution reads as follows:

"'Organ of state' means -

(a) Any department of state or administration in the national, provincial or local sphere of government; or

(b) any other functionary or institution -

(i) exercising a power or performing a function in terms of the Constitution or a provincial constitution; or

(ii) exercising a public power or performing a public function in terms of any legislation,

but does not include a court or a judicial officer."

19 See inter alia s 195 of the Constitution and the following: Ngxusa v Secretary, Department of Welfare, Eastern Cape Provincial Government 2000 (12) BCLR 1322 (E) 1329B. See Beukes "The Constitutional Foundation of the Implementation and Interpretation of the Promotion of Administrative Justice Act 3 of 2000" in Lange (ed) The Right to Know (2004) 6. See also Transnet Ltd v Chirwa 2007 (2) SA 198 (SCA) par 127; and Hoexter Administrative Law in South Africa 3-7 for a detailed discussion of the nature of "public power".

$20 \mathrm{~S} 33$ of the Constitution. See Beukes in Lange The Right to Know 4.

21 The idea of service to the people is aptly summarized in the opening statement of the "Batho Pele - 'People First': White Paper on Transforming Public Service Delivery"; and see Beukes in Lange (ed) The Right to Know 7. See also s 195(1)(e) of the Constitution.

22 Beukes in Lange (ed) The Right to Know 7.

23 Burns and Beukes Administrative Law Under the 1996 Constitution (2006) 49.

${ }^{24}$ Currie and De Waal The Bill of Rights Handbook 17.

${ }^{25} \mathrm{~S} 195$ of the Constitution.

26 Devenish The Constitution of South Africa (2005) 372. 


\section{ADMINISTRATIVE LAW ASPECTS OF STATE REGULATION OF SOUTH AFRICAN INSOLVENCY LAW}

\section{Introduction}

Before discussing certain aspects of administrative law pertaining to the Master as the existing supervisory authority in South African insolvency law, it is necessary to pause at the potential relevance of the Constitution in terms of the administrative law provision for the Master as a public body or institution. ${ }^{27}$ Administrative law can broadly be described as a branch of public law that regulates the way in which public authorities - and in certain instances also private entities - perform their powers and functions when implementing or giving effect to statutory and other empowering provisions. ${ }^{28}$ Hoexter is of the opinion that in present-day South Africa it is more accurate to regard administrative law as regulating the activities of bodies that exercise public powers or perform public functions, irrespective of whether those bodies are public authorities in a strict sense. ${ }^{29}$ The question what it is that makes a power or a function "public" has not yet been clearly answered by our courts, but such a power could essentially be described as a power inevitably associated with a duty to act in the public interest as opposed to a private interest. $^{30}$

Constitutional and administrative law are both extensive and specialized subjects and worthy of a study on their own. As previously mentioned the aim of this discussion is thus not to provide an in-depth discussion of the ambit of the administrative law in general but rather to discuss some of the basic principles of administrative law and, in particular PAJA, in order to determine their relevance to state regulation in South African insolvency law. In order to develop a better understanding of the purpose and operation of PAJA it will be essential to discuss initially certain important concepts such as "organ of state"; "administrative action" and "judicial review".

\section{The Promotion of Administrative Justice Act}

\section{General}

The Insolvency Act was enacted in the 1930s. Consequently, at the time it could not embrace the notion of accountability as currently understood and regulated in terms of the new Constitution and the new administrative law regime. When developing an innovative and efficient regulatory framework

27 Cf President of the Republic of South Africa v South African Rugby Football Union 2000 (1) SA 1 (CC) 142. See Mittalsteel SA Ltd (previously known as Iscor Ltd) v Hlatshwayo 2007 (1) All SA 1 (SCA) for a detailed discussion of the meaning of "public body".

28 See Hoexter Administrative Law in South Africa 2; Beukes in Lange (ed) The Right to Know 3.

29 Hoexter Administrative Law in South Africa 2.

30 In POPCRU v Minister of Correctional Services [2006] 12 BLLR 1212 (E) 53, Plasket J observed that "the elusive concept of public power is not limited to exercise of power that impacts on the public at large. Indeed, many administrative acts do not". See also Transnet Ltd v Chirwa supra; and Hoexter Administrative Law in South Africa 3. 
for South African insolvency law, it is therefore important to acknowledge the impact and effect of current legislation such as PAJA on the role of a supervisory body in insolvency law.

The Bill of Rights contains several provisions of significance for administrative law, and for the purposes of this study the right to just administrative action in particular represents the most important provision. In terms of section $33(1)^{31}$ of the Constitution everyone has the right to administrative action that is lawful, reasonable and procedurally fair. Section 33(3) thereof requires the enactment of national legislation to give effect to such right, and this requirement was given effect to by the enactment of PAJA.

The purpose of PAJA is thus to give effect to section 33 and to provide greater detail of the scope and application of the explicit constitutional right to administrative justice. It is a truism that the exercising of public power in a modern state depends fundamentally on discretionary decision-making by state officials at all levels of government and in this context the Master is no exception. ${ }^{33}$ It is equally trite that if a state is to meet the requirements of a constitutional democracy, those seeking benefits from the state, and those against whom the state seeks to enforce its powers, must have avenues to seek redress or at least a relatively independent regulation of such discretionary procedures in law. ${ }^{34}$

${ }^{31} \mathrm{~S} 33$ provides as follows: Just administrative action -

"(1) Everyone has the right to administrative action that is lawful, reasonable and procedurally fair.

(2) Everyone whose rights have been adversely affected by administrative action has the right to be given written reasons.

(3) National legislation must be enacted to give effect to these rights, and must -

(a) provide for the review of administrative action by a court or, where appropriate an independent and impartial tribunal;

(b) impose a duty on the state to give effect to the rights in subsections (1) and (2); and

(c) promote an efficient administration."

32 In Kiva v Minister of Correctional Services [2006] JOL 18512 (E) the court held that, because PAJA gives effect to a constitutional right, the provisions thereof must be generously interpreted. See Kunst, Meskin, Galgut Magid, Boraine and Burdette Meskin, Insolvency Law and its Operation in Winding-up (1990) (loose-leaf edition) par 1.8 (hereinafter "Meskin").

33 Apart from the Master, other officers may make decisions in terms of the Insolvency Act, eg, a magistrate issuing a search warrant in terms of s 69(3) of the Insolvency Act. In Le Roux v Magistrate, Mr Viana 2006 JDR 0562 (W) the court held that the issuing of a warrant by a magistrate amounted to a judicial and not an administrative function. It may also occur that procedural prerequisites regarding specific administrative actions may be more onerous on the parties than those imposed by the provisions of the PAJA. In HTF Developers (Pty) Ltd $v$ Minister of Environmental Affairs \& Tourism [2007] JOL 19542 (SCA) par 13, the SCA took the view that if the legislature chose to afford a party affected by particular administrative action greater procedural protection by means of the specific provisions of the Act, those provisions cannot be ignored in favour of less onerous prescriptions in general legislation such as the PAJA. See Meskin par 1.8.

34 See Corder "Reviewing Review: Much Achieved, Much More to Do" in Corder (ed) Realising Administrative Justice (2002) 1. 


\section{Administrative action}

The first phase in determining whether PAJA is applicable to the conduct of a public institution such as the Master is to determine whether the powers and functions of the Master can qualify as "administrative action" ${ }^{35}$ Section 33(1) of the Constitution determines that everyone has the right to administrative action that is lawful, reasonable and procedurally fair. However, this provision does not define administrative action. Instead this function has been left to PAJA ${ }^{36}$ and the following definition in section 1 of PAJA will apply: ${ }^{37}$

'administrative action' means any decision taken, or any failure to take a decision, by -

(a) an organ of state, when

(i) exercising a power in terms of the Constitution or a provincial constitution; or

(ii) exercising a public power or performing a public function in terms of any legislation; or

(b) a natural or juristic person, other than an organ of state, when exercising a public power or performing a public function in terms of an empowering provision, which adversely affects the rights of any person and which has a direct, external legal effect ..."

Accordingly, for an action or function to be classified as an administrative action in terms of the above definition, it has to comply with certain distinctive elements built into the definition of administrative action. ${ }^{38}$ One of these elements would be what constitutes a "decision". ${ }^{39}$ A decision, for the purposes of PAJA:

"means any decision of an administrative nature made, proposed to be made, or required to be made, as the case may be, under an empowering provision, including a decision relating to -

(a) making, suspending, revoking or refusing to make an order, award or determination;

(b) giving, suspending, revoking or refusing to give a certificate, direction, approval, consent or permission;

35 See the definition of "administrative action" in s 1 of PAJA. In Nedbank Ltd v Master of the High Court 2009 (3) SA 403 (W) the court expressed the view, inter alia, that when the Master gives effect to $s 417$ of the Companies Act, he does not act administratively, and accordingly PAJA does not apply to a decision by the Master to convene such enquiry. See also Currie The Promotion of Administrative Justice Act: A Commentary (2007) 44-92 for a detailed discussion of the concept "administrative action". See also Mazibuko $v$ City of Johannesburg (CCT 39/09) [2009] ZACC 28; Vuna Health Care Logistics (Mpumalanga) (Pty) Ltd $v$ MEC of Health and Social Development, Mpumalanga Provincial Government (5948/2011) [2012] ZAGPPHC 126 (22 June 2012).

36 Burns and Beukes Administrative Law Under the 1996 Constitution 6.

37 South African legal academics have, however, expressed concerns about the definition of administrative action in the Act and the overall view is that the definition is too narrow when read against the minimum requirements of the right to administrative justice in s 33 of the Constitution. Hoexter 2006 Acta Juridica 303.

38 For a detailed discussion of these elements refer to Hoexter Administrative Law in South Africa 163-221; and Burns and Beukes Administrative Law Under the 1996 Constitution 1931.

39 S $1(v)$ of PAJA. 
(c) issuing, suspending, revoking or refusing to issue a licence, authority or other instrument;

(d) imposing a condition or restriction;

(e) making a declaration, demand or requirement;

(f) retaining, or refusing to deliver up, an article; or

(g) doing or refusing to do any other act or thing of an administrative nature, and a reference to a failure to take a decision must be construed accordingly.'

The examples included in the definition do not constitute a complete list and it should be noted that the Act makes it clear that an administrative action should not be limited to administrative actions or decisions only, but may also include the failure to act. ${ }^{41}$ The definition of a "decision" also introduces two additional elements contained in the phrase "of an administrative nature, ${ }^{, 42}$ and the requirement that the decision must be taken in terms of an "empowering provision". ${ }^{43}$ Firstly, it is apparent that the purpose of the phrase "of an administrative nature" is to ensure that private law matters such as the conclusion of a contract are excluded from the ambit of the definition. ${ }^{44}$ The decision at issue should be of a public-law nature involving a relationship of inequality or subordination between the government and the individual or entity.

In terms of section 1 of the Act, "empowering provision" means a law, a rule of the common law, customary law, or an agreement, instrument or any other document in terms of which an administrative action was purportedly taken. ${ }^{46}$ The essence of this provision is the requirement that the exercise of administrative power must have an authoritative basis and that any public power must derive almost exclusively from some or other statutory measure or other empowering provision. The definition of "empowering provision" is exceptionally wide and extends beyond a law, a rule of the common law or customary law to include an agreement, instrument or other document in terms of which administrative action was purportedly taken. ${ }^{47}$

40 Definition in $\mathrm{S} 1$ of PAJA.

41 In Vulindlela Furniture Manufacturers v MEC, Department of Education and Culture 1998 (4) SA 908 (Tk) the court found that the words "lawful administrative action" contained in s 24(a) of the Interim Constitution are wide enough to include an omission to take administrative action where such a duty had been imposed; see Burns and Beukes Administrative Law Under the 1996 Constitution 21. In Standard Bank of SA Ltd v The Master of the High Court 2009 (5) SA 13 (E) par 90 the court stated that "[w]hile it is so that a failure to take a decision is a ground for review, a logical precondition is that the decision-maker is either under a legal duty to decide or that a duty to decide has been activated, for example by a request for a decision to be taken by a person with the standing to make such a request". See Meskin par 1.8 .

42 See also Minister of Health NO v New Clicks South Africa (Pty) Ltd (Treatment Action Campaign as Amici Curiae) 2006 (2) SA 311 (CC) Chaskalson CJ regarded the phrase "of an administrative nature" as bringing regulation-making within the scope of the definition of "decision". See Meskin par 1.8.

43 Hoexter Administrative Law in South Africa 205.

44 Burns and Beukes Administrative Law Under the 1996 Constitution 22.

45 Ibid.

46 Ibid.

47 PAJA excludes from the operation of the Act certain executive functions and powers. See s 1 of PAJA on the definition of "administrative action" and the exclusions listed there. 
A further element built into the definition of administrative action is that the decision has to be taken by an organ of state or by a private person exercising a public power or performing a public function. ${ }^{48}$ In the context of PAJA an organ of state bears the meaning assigned to it in section 239 of the Constitution. ${ }^{49}$ For purposes of this study it is important to note that the Supreme Court of Appeal held that any institution exercising a public power or performing a public function in terms of legislation is an organ of state. ${ }^{50}$ Although the case of Mittalsteel South Africa $v$ Hlatshwayo ${ }^{51}$ was not decided under section 33 of the Constitution but dealt with the right of access to information under section 32 of the Constitution, it clearly sets out the current approach to the term "organ of state" ${ }^{52}$ The court's approach to the definition places the focus on a functional rather than a control test. The question is therefore not whether the particular decision-maker is under the control of the state, but whether it performs a public function in terms of legislation. ${ }^{53}$ The concept of "organ of state" therefore plays a decisive role in determining whether an action is classified as an administrative action and whether it is subject to the application of the principles of just administrative action. ${ }^{54}$ Evidently, the Master does qualify as an organ of state, as it often exercises a public power or public function in terms of legislation, with the result that its decisions will be subject to the provisions of PAJA. ${ }^{55}$

The final requirements of the definition of an administrative action are that the decision has to affect someone else's rights adversely and must have a direct, external legal effect. ${ }^{56}$ These elements are taken to mean that a decision will qualify as an administrative action if it has the capacity to impact directly and immediately on individuals. ${ }^{57}$ The court held in Grey's Marine $^{58}$ that the phrase indicating that the action has to have an affect on a person's rights should be read to mean that the decision should have the capacity to affect rights adversely. ${ }^{59}$

With regard to the "direct external legal effect" requirement, it was held in Van Zyl v New National Party ${ }^{60}$ that the decision must be a final decision by an administrative decision-maker that constitutes a legally binding

48 See Fedsure Life Assurance Ltd v Greater Johannesburg Transitional Metropolitan Council 1999 (1) SA 374 (CC); President of the Republic of South Africa v South African Rugby Football Union supra; and Pharmaceutical Manufacturers Association of SA: In re Ex parte President of the Republic of South Africa 2000 (2) SA 674 (CC).

49 See fn 18 above.

50 Minister of Education, Western Cape v Governing Body, Mikro Primary School 20061 SA 1 (SCA).

51 Mittalsteel South Africa v Hlatshwayo supra.

52 Quinot Administrative Law Cases and Materials (2008) 202.

53 Ibid. See also Mittalsteel South Africa v Hlatshwayo supra par 7.

${ }_{54}$ Burns en Beukes Administrative Law Under the 1996 Constitution 14.

55 Meskin par 1.8.

56 See Joseph $v$ City of Johannesburg 2010 (4) SA 55 (CC) a judgment dealing with "direct, external legal effect.

57 Rudolph Student Manual: Applying the Promotion of Administrative Justice Act in Practice (2009) 138 (hereinafter "Rudolph Student Manual'). On file with the author.

58 Grey's Marine Hout Bay (Pty) Ltd v Minister of Public Works 2005 (6) SA 313 (SCA) 23.

59 Rudolph Student Manual 139.

602003 (10) BCLR 1167 (C). 
determination of another legal entity's rights. ${ }^{61} \mathrm{~A}$ "direct effect" would indicate that the decision is final, not in the sense of being irreversible, but simply that the decision has been made. The phrase "an external effect" indicates that the effect of the decision will be felt by someone other than the decision-maker. ${ }^{62}$ The final requirement, namely that it must have a "legal effect" could, according to Hoexter, be taken from the German rule that the decision must at least entail a determination of someone's rights, covering deprivations as well. ${ }^{63}$

In the case of President of the Republic of South Africa $v$ South African Rugby Football Union ${ }^{64}$ the Constitutional Court had to decide on the question whether the appointment of a commission of inquiry by the head of state fell to be regarded as administrative action. ${ }^{65}$ The court held that the administration is that part of government which is primarily concerned with the implementation of legislation, and not the formulation of policy. ${ }^{66}$ Thus in determining whether an act qualified as administrative in nature, the function mattered more than the functionary and the focus of the enquiry was not to be on the branch of government but on the nature of the power being exercised. The policy-laden nature of the act of appointing a commission and the origins of this power in the prerogative meant that it was not administrative but rather executive in nature. ${ }^{6}$

In the New Clicks ${ }^{68}$ case the Constitutional Court struggled with the concept of "administrative action" in terms of section 1 of PAJA and the four divergent approaches taken by the court in this case are revealing. ${ }^{69}$ The divergence underscores the sheer difficulty of deciding what is considered to be an administrative action and what is not in terms of PAJA. In the words of Hoexter: "... for if the Constitutional Court is defeated by section 1 of PAJA, what hope is there for the rest of us?"10

The above discussion on the meaning of the concept of "administrative action" is by no means all-inclusive or complete. It should be clear that PAJA

61 Van Zyl v New National Party supra par 86. See Currie The Promotion of Administrative Justice Benchbook (2001) 2 (hereinafter "Currie Benchbook"); and Burns and Beukes Administrative Law Under the 1996 Constitution 147.

62 Hoexter Administrative Law in South Africa 232.

63 Hoexter Administrative Law in South Africa 228 and 234. See also Union of Refugee Women $\checkmark$ Director, Private Security Industry Regulatory Authority 2007 (4) BCLR 339 (CC).

64 President of the Republic of South Africa $v$ South African Rugby Football Union supra.

65 Corder "Reinventing Administrative Law in South Africa" in Finn (ed) Sunrise or Sunset? Administrative Law in the New Millennium (2000) 100.

66 President of the Republic of South Africa v South African Rugby Football Union supra par 166.

67 President of the Republic of South Africa v South African Rugby Football Union supra par166-168.

68 Minister of Health NO v New Clicks South Africa (Pty) Ltd supra.

69 A majority of two judges agreed that the recommendations and regulations did not qualify as administrative action under PAJA and thus could not be reviewed under PAJA. They then held that review remained available in terms of the principle of legality and that the recommendations and regulations could also be reviewed under s 33 of the Constitution or under the common law. It is not clear from the judgment precisely which of these avenues was relied on in its subsequent review of the regulations. See Hoexter Administrative Law in South Africa 204.

70 Hoexter 2006 Acta Juridica 324. 
originates from section 33 of the Constitution and the definition of administrative action in the Act, although pieced together through various elements, should as far as possible be reconciled with the meaning that has been attributed thereto in the Constitution, so as to avoid constitutional invalidity. ${ }^{71}$ Thus, when determining whether an action by the Master could be classified as an administrative action it is apparent that every action to be incorporated under the scope of PAJA should first meet the requirements of the concept of administrative action as defined in the Act, and this would certainly entail an appraisal of the action measured against all the various elements built into the definition. ${ }^{72}$

Once it has been determined that an action constitutes "administrative action" the next phase will be to determine whether such action complies with the necessary requirements in terms of section 33(1) of the Constitution, namely whether the action can be classified as "lawful, reasonable and procedurally fair". ${ }^{73}$

\section{Lawful, reasonable and procedurally fair}

As mentioned above, section 33 states that everyone has the right to administrative action that is lawful, reasonable and procedurally fair. ${ }^{74} \mathrm{~A}$ "lawful" administrative action means in essence that administrative actions and decisions must be duly authorized by law and that any statutory requirement or precondition linked to the exercising of the power must be complied with. ${ }^{75}$ The requirement of "lawfulness" in relation to an "administrative action" as mentioned in both the Constitution and PAJA, is closely linked to the principle of legality as an important aspect of the rule of law, which in turn forms the basis of just administrative action in general. ${ }^{76}$ It should be noted that although an in-depth discussion of legality falls outside the scope of this article the principle nevertheless applies to all exercises of public power whether they amount to administrative action or not. ${ }^{77}$

The element of lawfulness covers all grounds generally associated with authority, jurisdiction and abuse of discretion. The important principle is that any exercise of power must be authorized by law. The Constitutional Court explained that it is "central to the conception of our constitutional order that the Legislature and Executive in every sphere are constrained by the principle that they may exercise no power and perform no function beyond

71 Hoexter Administrative Law in South Africa 247-251.

72 Burns en Beukes Administrative Law Under the 1996 Constitution 28. In Oosthuizen's Transport (Pty) Ltd v MEC, Road Traffic Matters, Mpumalanga 2008 (2) SA 570 (T) the court held that "administrative action" was action that had the capacity to affect legal rights (575IJ).

73 As stated in $\mathrm{s} 33(1)$ of the Constitution.

74 See Currie The Promotion of Administrative Justice Act: A Commentary Chapter 4.

75 Hoexter Administrative Law in South Africa 253.

$76 \mathrm{Ibid}$. For a case dealing with the lawfulness of an administrative action see Vorster and Another $v$ Department of Economic Development, Environment and Tourism, Limpopo Province 2006 (5) SA 291 (T) in which the court stated that lawfulness lies at the heart of administrative justice, and underpins the whole of the South African Constitution. See Meskin par 1.8.

77 See Maset/ha $v$ President of the Republic of South Africa 2008 (1) SA 566 (C). 
that conferred upon them by law". ${ }^{78}$ It is thus clear that administrators have no inherent powers and every incident of public power must be inferred from a lawful source, usually legislation.

The concept of "reasonableness" is one of the most elusive and variable concepts in our jurisprudence. It is impossible to assign a static and definitive meaning to it and the concept will no doubt develop as it is considered in a variety of circumstances. ${ }^{79}$ However, it is important to note that unlike the common-law position, ${ }^{80}$ reasonableness in terms of the new constitutional dispensation is a self-standing ground for the review of administrative action. The essence of the test now concerns an enquiry as to the presence of a rational connection between the decision made, the facts on which such decision is based and the reasoning provided for the decision. ${ }^{81}$ In Bato Star ${ }^{82}$ O'Regan J ruled that reasonableness must be determined on a case-by-case basis, depending on the circumstances of each case and taking into account the following: the nature of the decision; the identity and expertise of the decision-maker; the range of factors relevant to the decision; the reasons given for the decision; the nature of the competing interest involved and the impact of the decision on the lives of those affected. ${ }^{83}$

In Albutt $v$ Centre for the Study of Violence and Reconciliation ${ }^{84}$ the legal issue before the Constitutional Court was whether the President had a duty, prior to deciding whether applicants under the special scheme should be pardoned, to afford the victims of their crimes a hearing whether under PAJA or on some other basis. ${ }^{85}$ Ngcobo CJ held that this was indeed the case. What is interesting about the decision is the novel route which the Chief Justice took to reach this conclusion: he chose to leave the questions arising under PAJA unanswered, overruling the High Court's conclusions in this regard, ${ }^{86}$ and instead held that the President's refusal to hear the victims was irrational. ${ }^{87}$ In other words, he applied rationality review - a form of substantive judicial review based on the principle of legality and the rule of

78 Fedsure Life Insurance Ltd v Greater Johannesburg Transitional Metropolitan Council 1999 (1) SA 374 (CC) par 58. See Hoexter Administrative Law in South Africa 255.

79 Govender "Administrative Law as a Surrogate for Human Rights Law" in Corder (ed) Realising Administrative Justice (2002) 45. See Hoexter Administrative Law in South Africa Chapter 6.

80 Under the common law unreasonableness alone was not enough. The courts required an additional element such as mala fides or failure by the decision-maker to apply his or her mind to the matter. See Union Government v Union Steel Corporation 1928 AD 220236.

81 See Carephone (Pty) Ltd v Marcus NO 1998 (10) BCLR 1326 (LAC); and Nieuwoudt v Chairman, Amnesty Committee, Truth and Reconciliation Committee 2002 (2) SA 143 (C) 155.

82 Bato Star Fishing (Pty) v Minister of Environmental Affairs supra.

83 Hoexter Administrative Law in South Africa 348.

842010 (3) SA 293 (CC).

85 Price "Rationality Review of Legislation and Executive Decisions: Poverty Alleviation Network and Albutt' 2010 SALJ 580.

86 Price 2010 SALJ 580. See Albutt v Centre for the Study of Violence and Reconciliation supra par 82-83.

87 Price 2010 SALJ 584. See Albutt v Centre for the Study of Violence and Reconciliation supra par 74. 
law - in order to reach a procedural conclusion, namely, that the victims had a right to be heard.

Generally it is accepted that the reasonableness test is often accompanied by an enquiry into the rationality of the decision as well as the proportionality of its outcome. ${ }^{89}$ Rationality relates primarily to preventing an abuse of discretionary power or arbitrary decision-making and is considered to be the minimum-threshold requirement for a valid exercise of public power. ${ }^{90}$ This test is now codified in section 6(2)(f)(ii) of PAJA and requires that an administrative action be rationally connected to the purpose for which it was taken; the purpose of the empowering provision; the information before the administrator; or the reasons given for it by the administrator. ${ }^{91}$ Proportionality on the other hand means trying to avoid an undue imbalance between the adverse and the beneficial effects or consequences of an action. ${ }^{92}$ Essentially, this is about establishing proportionality between the means and the ends and by comparing and weighing the advantages and disadvantages of the measures against each other. ${ }^{93}$ Where appropriate the administrator should therefore be sensitized to use less restrictive or oppressive means to achieve the purpose of the administrative action. ${ }^{94}$

Apart from the requirements of lawfulness and reasonableness, section 33(1) of the Constitution guarantees everyone a right to administrative action that is "procedurally fair". Section 3(1) of PAJA also states that "administrative action which materially and adversely affects the rights or legitimate expectations of any person must be procedurally fair". ${ }^{55}$ The

88 Ibid.

89 See also Hoexter "Unreasonableness in the Administrative Justice Act" in Lange (ed) The Right to Know (2004) 149.

90 Pharmaceutical Manufacturers Association of South Africa In Re: Ex Parte Application of the President of the RSA 2000 (3) BCLR 241 (CC) par 85

91 One consequence of this minimum threshold is that once complied with by the decisionmaker a court will be reluctant to interfere with the decision merely because the court holds a different view. Such reasoning upholds the doctrine of the separation of powers and allows for rational choices to be made by the executive on matters that fall primarily within the domain of the executive. See also Bel Porto School Governing Body $v$ Premier of the Province, Western Cape 2002 (9) BCLR 891 (CC) par 45.

92 Hoexter in Lange (ed) The Right to Know 154. See also Hoexter Administrative Law in South Africa 343.

93 Hoexter Administrative Law in South Africa 344.

94 In recent years the courts have moved towards adopting a more objective approach to reasonableness. Eg, in Standard Bank of Bophuthatswana Ltd v Reynolds 1995 (3) BCLR 305 (B), 1995 (3) SA 74 (B), the court departed from the test of "gross unreasonableness" and found that the less stringent test of "unreasonableness" should be adopted. It should, however, again be stated that "reasonableness" has a wide range of variation and no single meaning can be attributed to it. See Nel NO v The Master 2005 (1) SA 276 (SCA) for a consideration of "reasonableness" in the context of the Master's power to reduce or increase the "reasonable remuneration" of a liquidator. See also Hoexter Administrative Law in South Africa 306; Burns en Beukes Administrative Law Under the 1996 Constitution 151; and Hoexter in Lange (ed) The Right to Know 154.

95 For a case dealing with procedural unfairness, see Dunn v Minister of Defence 2006 (2) SA $107(\mathrm{~T})$. 
concept of procedural fairness is flexible and the range of situations to which it may apply is extensive. ${ }^{96}$

For current purposes it would suffice to point out some of the essential features of this requirement. At common law, procedural fairness was associated with the rules of natural justice which were based on the audi alteram partem and nemo iudex in sua causa principles. ${ }^{97}$ In terms of these principles an affected person was entitled to be afforded an opportunity to be heard, to be informed about all relevant information relating to the decision and to be granted a hearing that was unbiased and impartial. ${ }^{98}$ By virtue of section 3 of PAJA the common-law position has now become part and parcel of the statutory requirements for procedural fairness.

Section 3 provides for three categories of rules aimed at ensuring procedural fairness. In the first category mandatory procedures are specified $^{99}$ which require the decision-maker to give adequate notice ${ }^{100}$ of the nature and purpose of the action; a reasonable opportunity to make representations; a clear statement of the administrative action; adequate notice of any right to review or appeal; and adequate notice of the right to request reasons in terms of section 5 of PAJA.

In the second category, ${ }^{101}$ additional procedural safeguards of a discretionary nature are provided for, such as the right to legal representation, the right to present and dispute information and the right to appear in person. In the third and last instance section 3 of PAJA follows the dubious approach of allowing for a departure from the mandatory requirements if it is reasonable and justifiable in the circumstances. The only consolation is that the envisaged departure from the mandatory prescriptions must be justifiable with reference to a range of factors listed in the provision itself. ${ }^{102}$ The effect of allowing a decision-maker to depart from the mandatory-fair procedure requirements is that a limitation of the right to procedural fairness becomes permissible ex lege. To the extent that such a limitation may interfere with the general guarantees in section 33 of the Constitution, section 36 of the Constitution will have to be complied with.

In the final analysis two related issues warrant attention. The first is that the remedy available to an affected person remains a procedural as opposed to a substantive one. This is the essence of section 33 of the Constitution which provides for procedural fairness only. Equally, it will also be the case with regard to the second issue, namely the protection of a legitimate expectation (as opposed to a right) in terms of section 3(1) of

96 Du Preez v Truth and Reconciliation Commission 1997 (3) SA 204 (A); and Mose v Minister of Education, Western Cape 2009 (2) SA 408 (C). See also Burns en Beukes Administrative Law Under the 1996 Constitution 206.

97 Hoexter Administrative Law in South Africa Chapter 6.

98 See for instance South African Roads Board v Johannesburg City Council 1991 (4) SA 1 (A); and Administrator Natal $v$ Sibiya 1992 (4) SA 532 (A).

$99 \mathrm{~S} 3(2)(b)$.

${ }^{100}$ On adequate notice see Bushula v Permanent Secretary, Dept of Welfare, Eastern Cape 2000 (7) BCLR 728 (E); and Cape Killarney Property Investments (Pty) Ltd v Mahamba 2000 (2) SA 67 (C).

$101 \mathrm{~S} 3(3)$.

${ }^{102}$ Ss $3(4)(a)$ and (b). 
PAJA. As the law currently stands, the violation of a legitimate expectation does not entitle the affected person to claim specific performance and the courts will limit their enquiry to what is procedurally the most appropriate remedy. ${ }^{103}$ However, it may be argued that the time has come to consider the right to a substantive remedy in this instance, especially in view of the courts' obligation to provide appropriate relief in terms of section 38 of the constitution in the case of a violation of a right in the Bill of Rights and the vast material in general on the duty of a state to provide for effective remedies in response to the violation of a right. ${ }^{104}$

\section{Judicial review and remedies under PAJA}

In order to set the stage for a discussion of the accountability of a supervisory authority in insolvency law, it is necessary to mention that apart from the most popular route of statutory review, the introduction of the Constitution now also presents alternative measures of relief. The Insolvency Act makes provision for the Master's decisions, rulings and orders to be reviewed by a court of law and the bulk of review proceedings and body of case law still represent actions taken under this procedure. However, apart from the statutory relief presented by the Insolvency Act the law relating to judicial review has undergone a fundamental change by virtue of the introduction of the new constitutional dispensation. ${ }^{106}$

There are different types of review proceedings in South African law, including the review of the proceedings of inferior courts; ${ }^{107}$ automatic review $^{108}$ and judicial review in the constitutional sense; ${ }^{109}$ judicial review in the administrative-law sense ${ }^{110}$ and special statutory review. ${ }^{111}$ It should also be noted that there are now also five different pathways to administrative review, namely common-law review; ${ }^{112}$ review proceedings in terms of PAJA; review in terms of section 33 of the Constitution; the constitutional principle of legality; and special statutory review. ${ }^{113}$ From a South African

${ }^{103}$ See for instance Administrator Transvaal v Traub 1989 (4) SA 731 (A); Bushbuck Ridge Border Committee v Government of the Northern Province 1999 (2) BCLR 193 (T); and Meyer v Iscor Pension Fund 2003 (2) SA 715 (SCA).

${ }^{104}$ See also Fose $v$ Minister of Safety and Security 1997 (1) BCLR 851 (CC).

${ }^{105} \mathrm{~S} 151$ of the Insolvency Act of 1936 . See Nel NNO $v$ The Master supra.

${ }^{106}$ The judicial review of administrative actions arising from PAJA as well as direct constitutional review under $\mathrm{s} 33$ of the Constitution are now also available to the ordinary citizen seeking relief. See Currie The Promotion of Administrative Justice Act: A Commentary Chapter 7.

${ }^{107}$ S 24 of the Supreme Court Act 59 of 1959.

${ }^{108}$ Certain statutes make provision for the decisions of magistrates to be reviewed "automatically" by judges.

109 Power of the courts to scrutinize and declare unconstitutional any type of legislation, original or delegated, or state conduct that infringes on the rights in the Bill of Rights or otherwise offends against provisions of the Constitution. See Hoexter Administrative Law in South Africa 112.

110 "Judicial review" according to administrative law refers more specifically to the power of the courts to scrutinize and set aside administrative decisions or rules on the basis of certain grounds of review. Hoexter Administrative Law in South Africa 113.

111 The legislature may and often does confer on the courts a statutory power of review. See Hoexter Administrative Law in South Africa 113.

112 Hoexter Administrative Law in South Africa 515.

${ }^{113}$ Hoexter Administrative Law in South Africa 113. 
perspective judicial review remains the most significant remedy against maladministration, as is evident from the vast amount of administrative-law literature available on the subject. This part of the discussion will only offer a brief overview of the most important principles regarding judicial control over the administrative powers and functions of the Master, which include review in terms of PAJA.

PAJA provides for the most immediate justification for judicial review, based on the constitutional mandate in section 33(3) to give effect to the administrative justice rights in the Constitution and to provide for the review of administrative action by a court or, where appropriate, an independent and impartial tribunal. ${ }^{115}$ PAJA does not replace section 33 of the Constitution but in effect now provides for the primary or default pathway to review. ${ }^{116}$ Since PAJA provides the most immediate source of review, the direct constitutional review under section 33 is available only infrequently typically in cases where original legislation is challenged on the basis that it unjustifiably limits the rights in section 33 , or where the decision-maker has acted outside the scope of the constitutional powers assigned to him or her. ${ }^{117}$ Direct constitutional review will also be appropriate where PAJA itself is impugned for failure to "give effect to" the administrative-justice rights. ${ }^{118}$ The limited application of section 33 accords with the principle of avoidance first expressed in $S \vee$ Mhlungu, ${ }^{119}$ which requires resort to be had to a specific statutory remedy or the common law before constitutional remedies are sought. ${ }^{120}$

Critically, however, it should be kept in mind that the application of both PAJA and section 33 is confined to the category of "administrative action". ${ }^{121}$ This implies that in every case of judicial review it is necessary to establish initially whether the action qualifies as an administrative action which may in review proceedings act as a limiting device in both cases. As a limiting factor, this qualification does not mean that the particular action is altogether unreviewable. In POPCRU v Minister of Correctional Services ${ }^{122}$ the court held that the fact that some forms of administrative action may be excluded from the limited statutory definition does not mean that these actions are not reviewable in terms of the High Court's inherent and constitutional jurisdiction. ${ }^{123}$ The court also found that judicial review is not limited to administrative acts that impact on the public at large, but extends to public functionaries who are required to act in the public interest. ${ }^{124}$

\footnotetext{
${ }^{114}$ It should be kept in mind that the constitutional review in terms of the principle of legality is not excluded.

${ }^{115}$ S 33 of the Constitution; and Hoexter Administrative Law in South Africa 114.

${ }^{116}$ Hoexter Administrative Law in South Africa 118.

117 Ibid.

118 Hoexter Administrative Law in South Africa 528.

1191995 (3) SA 867 (CC).

120 See Jayiya v MEC for Welfare, Eastern Cape Provincial Government 2004 (2) SA 611 (SCA).

${ }^{121}$ Hoexter Administrative Law in South Africa 115.

122 POPCRU v Minister of Correctional Services supra.

${ }^{123}$ Meskin par 1.8.

124 Ibid.
} 
The first stage on the road to just and lawful administrative action would thus be to determine whether such action qualifies as an "administrative action" in accordance with PAJA. It will then be evident that apart from certain exceptions, ${ }^{125}$ the action or decision will be controlled by the legal machinery of general administrative law consisting of the constitutional right to administrative justice and the legislative provisions in PAJA. ${ }^{126}$ The extent to which the right to lawful, reasonable and procedurally fair administrative action in the Constitution guarantees the state's accountability and transparency cannot be underestimated, and is reflected in the right of an individual affected by the administrative action to request written reasons and ultimately to challenge the action by way of judicial review. ${ }^{127}$

\section{Judicial review of administrative action}

Although judicial review is not the only method of control of administrative actions, it is regarded as the most effective. The new constitutional dispensation has fundamentally changed the role of the courts, and the courts are now required to give content and meaning to the values and principles as contained in the Constitution. ${ }^{128} \mathrm{~A}$ clear distinction should be made between judicial appeal where the court is interested in the merits of the case and whether the administrator's decision was correct or incorrect, ${ }^{129}$ and judicial review where the function of the court is purely to examine the legality of the administrative actions in the context of section 6 of PAJA, which is an enquiry into the way in which the decision was taken. ${ }^{130}$

Extensive grounds ${ }^{131}$ are provided for the judicial review ${ }^{132}$ of administrative actions, and these include actions that are not rationally connected to the purpose for which they were taken, ${ }^{133}$ the information at the disposal of the administrator ${ }^{134}$ or the reasons furnished by the

${ }^{125}$ See definition in $\mathrm{s} 1$ of PAJA. See also Minister of Health NO $v$ New Clicks South Africa (Pty) Ltd supra; and Hoexter Administrative Law in South Africa 210.

${ }^{126}$ Hoexter Administrative Law in South Africa 9.

${ }^{127}$ See in general ss 5 and 6 of PAJA.

${ }^{128}$ Burns and Beukes Administrative Law Under the 1996 Constitution 284.

${ }^{129}$ Burns and Beukes Administrative Law Under the 1996 Constitution 285.

${ }^{130}$ Ibid.

${ }^{131}$ S 6(2) of PAJA. For a case dealing with reviews in terms of s 6(2) of the Act, see Dunn v Minister of Defence supra.

${ }^{132}$ As to the test to be applied in such review proceedings, see Trinity Broadcasting, Ciskei $v$ Independent Communications Authority of SA 2004 (3) SA 346 (SCA).

${ }^{133}$ In Trinity Broadcasting (Ciskei) v Independent Communications Authority of South Africa supra it was held that the review threshold for administrative action is rationality. In this case the court held that, in requiring reasonable administrative action, the Constitution did not intend that in review proceedings the action had to be tested against the reasonableness of the merits of the action in the same way as an appeal, and as the test for rationality was an objective one, it was immaterial whether the functionary acted in the belief, in good faith, that the action had been rational. For more on the requirement of rationality, see Rustenburg Platinum Mines Ltd (Rustenburg Section) v CCMA 2007 (1) SA 576 (SCA). See Meskin par 1.8.

${ }^{134}$ In accordance with the principle of audi alteram partem, fairness may dictate that a person who may be affected adversely by a decision should be afforded the opportunity to make representations. Such representations should be capable of being made before or after a decision, or both before and after a decision; see Du Bois $v$ Stompdrift-Kamanassie Besproeiingsraad 2002 (5) SA 186 (C). See Meskin par 1.8. 
administrator. ${ }^{135}$ Such review proceedings must be instituted without unreasonable delay, ${ }^{136}$ but not later than 180 days after the conclusion of the internal remedies, or, where no internal remedies exist, within 180 days after the person who was informed of the administrative action, became aware of the action and the reasons for it, or might reasonably have been expected to have become aware of it and the reasons for that. ${ }^{137}$ The periods of 90 and 180 days may be extended by agreement between the parties, or where the interests of justice so require, by the court. ${ }^{138}$

The requirements for administrative legality are laid down in section 6(2) of PAJA, which reads as follows:

"(2) A court or tribunal has the power to judicially review an administrative action if -

(a) the administrator who took it -

(i) was not authorised to do so by the empowering provision;

(ii) acted under a delegation of power which was not authorised by the empowering provision; or

(iii) was biased or reasonably suspected of bias;

(b) a mandatory and material procedure or condition prescribed by an empowering provision was not complied with;

(c) the action was procedurally unfair;

(d) the action was materially influenced by an error of law;

(e) the action was taken -

(i) for a reason not authorised by the empowering provision;

(ii) for an ulterior purpose or motive;

(iii) because irrelevant considerations were taken into account or relevant considerations were not considered;

(iv) because of the unauthorised or unwarranted dictates of another person or body;

(v) in bad faith; or

(vi) arbitrarily or capriciously;

(f) the action itself -

(i) contravenes a law or is not authorised by the empowering provision; or

(ii) is not rationally connected to -

${ }^{135}$ In the Kiva case supra, the court held that the applicant was entitled to reasons, not only because his rights had been affected, but also because without reasons he was unable to exercise his right of review. The court also stated that in law "reasons" are statements that explain why a decision was taken.

${ }^{136}$ In PG Bison Ltd v Johannesburg Glassworks (Pty) Ltd (In Liquidation) 2006 (4) SA 535 (W) the court, in deciding a point in limine, held that an application for the review of the Master's decision to expunge a claim brought some thirteen months after the applicant became aware of the expungement constituted an unreasonable delay in bringing the review proceedings. Although the application was dismissed on different grounds, the court held that the application fell to be dismissed solely on the ground of the applicant's unreasonable delay in bringing the application, taking into account s 7(1)(a) and (b) of the PAJA. See Meskin par 1.8 .

${ }^{137}$ S 7(1) of PAJA. In Sasol Oil (Pty) Ltd v Metcalfe NO 2004 (5) SA 161 (W) it was held that the period of 180 days provided for in Act 3 of 2000 overrides the provisions of conflicting earlier legislation providing for shorter time frames. In this case the relevant legislation provided for a period of 30 days within which to bring review proceedings. The court found that because PAJA was constitutional legislation, the time frame of 180 days had to prevail over the earlier legislation providing for a time frame of 30 days. See Meskin par 1.8.

${ }^{138} \mathrm{~S} 9$ of PAJA. 
(aa) the purpose for which it was taken;

(bb) the purpose of the empowering provision;

(cc) the information before the administrator; or

(dd) the reasons given for it by the administrator;

(g) the action concerned consists of a failure to take a decision;

(h) the exercise of the power or the performance of the function authorised by the empowering provision, in pursuance of which the administrative action was purportedly taken, is so unreasonable that no reasonable person could have so exercised the power or performed the function; or

(i) the action is otherwise unconstitutional or unlawful. ${ }^{139}$

The grounds for review listed in section 6 of PAJA can therefore be divided into four different categories. The first ground of review manifests itself in the absence of authority. An absence of authority is present when the administrator who took the decision was not authorized to do so by an empowering provision; ${ }^{140}$ acted under a delegation of power that was not authorized by the empowering provision; ${ }^{141}$ was biased or reasonably suspected of bias; ${ }^{142}$ or the action itself contravened a law or was not authorized by the empowering provision. ${ }^{143}$ Combined, these grounds for review place an obligation on an administrator to ensure that he or she had the necessary legal authority to make a decision and that the prescribed powers were exercised within the scope of the empowering provision. ${ }^{144}$

The second category deals with the way in which the decision was taken and the factors or circumstances taken into consideration by the decisionmaker. ${ }^{145}$ In this instance the grounds for review relate to non-compliance by the decision-maker with a mandatory and material procedure or condition prescribed by an empowering provision; the taking of a decision in a procedurally unfair manner, under the influence of an error of law, for an unauthorized reason or for an ulterior purpose or motive. Also belonging to this category are decisions based on irrelevant considerations or taken under the unauthorized dictates of another person, in bad faith or arbitrarily or capriciously.

The third category relates to the rationality requirement, which was dealt with above. ${ }^{146}$

In the fourth category, a combination of common-law grounds for review and a catch-all possibility can be found. The common-law grounds relate to the instance where the decision-maker has failed to take the decision or where the exercise of the power or the performance of the function was so unreasonable that no reasonable person could have so exercised the power or performed the function. In terms of this category an administrative action can be reviewable when it is otherwise unconstitutional or unlawful. ${ }^{147}$

${ }^{139} \mathrm{~S} 6$ of PAJA.

${ }^{140} \mathrm{~S} 6(2)(\mathrm{a})(\mathrm{i})$ of PAJA.

${ }^{141} \mathrm{~S}$ 6(2)(a)(ii) of PAJA.

${ }^{142} \mathrm{~S} 6$ (2)(a)(iii) of PAJA.

${ }^{143}$ S6(2)(f)(i) of PAJA.

${ }^{144}$ Rudolph Student Manual 199.

${ }^{145} \mathrm{~S} 6(2)(\mathrm{b})-(\mathrm{e})$.

${ }^{146} \mathrm{~S} 6(2)(\mathrm{f})(\mathrm{ii})$.

${ }^{147}$ S $6(2)(g)-(i)$. 
Section 6 should also be read with section 7 of PAJA. According to section 7 , review proceedings are only possible once all internal remedies provided for in any other law have been exhausted. ${ }^{148}$ The court is thus obliged to turn the applicant away if it becomes apparent that the internal remedies available to the applicant have not been exhausted. ${ }^{149}$ The court may only grant an exception to this rule in exceptional circumstances and where it is in the interest of justice to do so. ${ }^{150}$ The duty to exhaust internal remedies refers only to remedies specifically provided for in the legislation with which the case is concerned. In Reed $v$ Master of the High Court ${ }^{151}$ Plasket $\mathrm{J}$ laid emphasis on the fact that this provision does not place an obligation on a person to deplete all possible avenues of redress such as an application to the Public Prosecutor prior to resorting to judicial review. ${ }^{1}$

An example of such an internal remedy is to be found in section $57(7)$ of the Insolvency Act. The section reads as follows:

"Any person aggrieved by the appointment of a trustee or the refusal of the Master to confirm the election of a trustee or to appoint a person elected as a trustee, may within a period of seven days from the date of such appointment or refusal request the Master in writing to submit his or her reasons for such appointment or refusal to the Minister."

In summary, the grounds for review relate to requirements that an administrative action should be lawful, reasonable and procedurally fair. The proper extent of judicial control over the administration is a question of recurrent interest in administrative law, no doubt because it can never be answered absolutely. Judicial review will always be characterized by a continuous tension between the two essential aims of administrative law: to empower officials and give them the necessary freedom to do their work, and to control those powers and to limit their freedom in order to protect the rights of those affected by their decisions. ${ }^{154}$

${ }^{148}$ S 7(2)(a) of PAJA. In Nichol and Another $v$ Registrar of Pension Funds and Others 20081 SA 383 (SCA) the SCA held that PAJA made it compulsory for an aggrieved party to exhaust the internal remedies, unless exempted from doing so by way of an application under $s$ $7(2)$ (c). This will be the case if the court is satisfied that there are exceptional circumstances requiring immediate intervention by the court rather than recourse to an internal remedy (such as where the available internal remedy would not provide the applicant with effective redress) (par 18 391A-B), and if it is in the interest of justice that the exemption be granted (par 15 390B-C). Such exceptional circumstances must exist before or at the time of the institution of the review proceedings (par 16 and $17390 \mathrm{C}-\mathrm{G}$ ). See Meskin par 1.8.

${ }^{149}$ Hoexter Administrative Law in South Africa 541. It should be noted that in Eye of Africa $v$ Nicola Shear (863/10) [2011] ZASCA 226 (30 November 2011) it was held that s 7 applies only to an administrative action. The appellant contended that the respondent has failed to exhaust internal remedies as required by $\mathrm{s} 7$ of the Promotion of Administrative Justice Act 3 of 2000 (PAJA) which the court rejected as a submission without merit as s 7 applies only to administrative action.

${ }^{150} \mathrm{~S} 7(2)(\mathrm{C})$ of PAJA.

1512005 (2) All SA 429 (E).

152 Hoexter Administrative Law in South Africa 541. See also Reed v Master of the High Court supra at par 20.

153 S 57(7) of the Insolvency Act.

${ }^{154}$ It should be noted that in an appropriate case "as a matter of public interest in the finality of administrative decisions and the exercise of administrative functions, considerations of pragmatism and practicality" may compel the court to exercise its discretion to decline to set aside an invalid administrative act. See Chairperson, Standing Tender Committee v JFE 


\section{Insolvency Act or PAJA?}

One of the questions that may arise when the impact of PAJA on South African insolvency law is examined, and in particular the role of the Master, is which Act will prevail if a complainant has a choice between redress through proceedings provided for in the Insolvency Act, on the one hand, and PAJA, on the other. Section 111 of the Insolvency Act could serve as an example of such a predicament. ${ }^{155}$ According to section 111 of the Insolvency Act:

"(1) The insolvent or any person interested in the estate may, at any time before the confirmation of the trustee's account, in terms of section one hundred and twelve, lay before the Master in writing any objection, with the reasons therefore, to that account.

(2) If the Master is of the opinion that any such objection is well founded or if, apart from any objection, he is of the opinion that the account is in any respect incorrect or contains any improper charge or that the trustee acted mala fide, negligently or unreasonably in incurring any costs included in the account and that the account should be amended, he may direct the trustee to amend the account or may give such other direction in connection therewith as he may think fit: Provided that -

(a) any person aggrieved by any such direction of the Master or by the refusal of the Master to sustain an objection so lodged, may apply by motion to the court within fourteen days as from the date of the Master's direction, or as from the date of intimation to the objector of the Master's refusal to sustain his objection, after notice to the trustee, for an order to set aside the Master's decision and the court may thereupon confirm the account or make such order as it thinks fit:" (author's own emphasis added).

If the Master is of the opinion that the objection is well founded he or she will direct the trustee to amend the account or otherwise reject the objection and proceed to confirm the account according to section 112 of the Insolvency Act. A person who feels aggrieved by the decision of the Master may approach the court within 14 days for relief. After the expiry of the 14day period the Master, if he or she has not received notice of the application to court, will proceed to confirm the account. It should be noted that the confirmation "shall be final save as against a person who may have been permitted by the court before any dividend has been paid under the account, to reopen it." It should be noted that if a trustee has according to the distribution account paid out dividends to creditors, a dividend once paid under a confirmed account cannot be disturbed or reclaimed. ${ }^{156}$

The Insolvency Act therefore includes a provision attached to a time-scale in order for an aggrieved person to approach the High Court, and it is clear according to South African Bank of Athens $v$ Sfier $^{157}$ that it was undoubtedly the intention of the legislator that the objector should follow this route laid

Sapela Electronics (Pty) Ltd 2008 (2) SA 638 (SCA) 649J and 650E. See also Hoexter Administrative Law in South Africa 550-551.

${ }^{155}$ S 107-112 of Insolvency Act. See also Bertelsmann, Evans, Harris, Kelly-Louw, Loubser, Roestoff, Smith, Stander and Steyn Mars: The Law of Insolvency in South Africa (2008) $513-545$.

${ }^{156} \mathrm{~S} 112$ of the Insolvency Act. See Mars 537.

1571991 (3) SA 534 (T) 539. See also Gilbey Distillers \& Vintners (Pty) Ltd v Morris 1991 (1) SA 648 (A) 655 . 
down by section 111. It should also be noted that the outcome of the statutory-review procedure is final and cannot be reversed by any other remedy. Where the offending action qualifies as an "administrative action" an applicant may be in the position to choose between the remedies offered by the regime of statutory review as mentioned here in section 111, or those available under PAJA.

Consequently, the situation sometimes occurs that enabling legislation stipulates its own requirements relating to the time frame for review, and the question then is whether such a stipulation prevails over section $7(1)$ of PAJA or vice versa. ${ }^{159}$ This point arose in Sasol Oil (Pty) Ltd $v$ Metcalfe NO. ${ }^{160}$ While the maxim generalia specialibus non derogant rule suggests that the special time limit for review would override PAJA, Willis $J$ took the opposite view in light of the extraordinary status of PAJA as constitutional and "universal" legislation. ${ }^{161}$ On appeal the court found it unnecessary to decide the point relating to the formal supremacy of PAJA, noting merely that it was a novel one and had been the subject of academic debate.

In Sidumo $v$ Rustenburg Platinum Mines $L d^{163}$ the Supreme Court of Appeal dealt with the question whether PAJA was applicable to review of a Commission for Conciliation, Mediation and Arbitration ${ }^{164}$ arbitration award and confirmed that the only tension that arose in view of the importation of PAJA was the difference in time frames in relation to reviews under section 145 of the Labour Relations Act ${ }^{165}$ and PAJA respectively. ${ }^{166}$ The court stated that the difference is but one of the symptoms of a lack of cohesion between the provisions of PAJA and the Labour Relations Act. ${ }^{167}$ On appeal to the Constitutional Court the court concluded: "that nothing in section 33 of the Constitution precludes specialized legislative regulation of administrative actions such as section 145 of the Labour Relations Act alongside general legislation such as PAJA. Of course, any legislation giving effect to section 33 must comply with its prescripts". ${ }^{168}$ Ngcobo $\mathrm{J}$ indicated in Zondi v MEC for Traditional and Local Government Affairs ${ }^{169}$ that: "decision-makers who are entrusted with authority to make administrative decisions by any statute are

${ }^{158}$ Hoexter Administrative Law in South Africa 537.

159 Ibid. See Plasket "The Exhaustion of Internal Remedies and Section 7(2) of the Promotion of Administrative Justice Act 3 of 2000" 2002 SALJ 50.

160 Sasol Oil (Pty) Ltd v Metcalfe NO supra 166C.

$161 \mathrm{Ibid}$. See Hoexter Administrative Law in South Africa 537.

162 See MEC for Agriculture v Sasol Oil 2006 (5) SA 483 (SCA). In Sasol Oil (Pty) Ltd v Metcalfe supra it was held that the period of 180 days provided for in PAJA overrides the provisions of conflicting earlier legislation providing for shorter time frames. In this case the relevant legislation provided for a period of 30 days within which to bring review proceedings. The court found that because PAJA was constitutional legislation, the time frame of 180 days had to prevail over the earlier legislation providing for a time frame of 30 days. See Meskin par 1.8 .

1632008 (2) SA 24 (CC).

${ }^{164}$ Hereinafter "the CCMA".

${ }^{165}$ Act 66 of 1965 . Hereinafter "Labour Relations Act".

${ }^{166}$ Van Niekerk, Christianson, McGregor, Smit and Van Eck Law@work (2009) 49.

167 The same principles could therefore also be applied to the difference in time-scales between PAJA and the Insolvency Act.

168 Sidumo v Rustenburg Platinum Mines Ltd supra par 91.

1692005 (3) SA 589 (CC). 
... required to do so in a manner that is consistent with PAJA". In other words, unless the legislation is actually inconsistent with PAJA, the provisions in the enabling legislation will be applicable and where feasible PAJA will be read into the enabling legislation.

Hoexter is of the opinion that the idea that PAJA automatically prevails over all other more specific legislation is a drastic one and would surely be difficult to justify on practical grounds. It would be easier to think of reasons why it may be desirable or necessary for the enabling legislation to impose special requirements in relation to particular statutory regimes. ${ }^{170}$ In the context of the tension between the time limit set according to section 111 and the 180-days' time limit in PAJA, it could be submitted that the clear intention of the legislature was to ensure a speedy finalization of the administration of the insolvent estate, as it would not be to the advantage of the South African economy if the administration were to be unduly delayed.

In HTF Developers (Pty) Ltd $v$ Minister of Environmental Affairs \& Tourism, ${ }^{172}$ the Supreme Court of Appeal took the view that if the legislature chose to afford a party affected by particular administrative action greater procedural protection by means of the specific provisions of the Act, those provisions cannot be ignored in favour of less onerous prescriptions in general legislation such as PAJA.

Section 111 of the Insolvency Act could also be described as a limitation with the object to confine access to judicial relief rather than prevent it altogether. ${ }^{173}$ Such clauses typically set time limits within which applications must be bought. In a recent case of Brümmer $v$ Minister of Social Development, ${ }^{174}$ a 30 -day period for applications to court under $s$ 78(2) of the Promotion of Access to Information Act ${ }^{175}$ was found to be inconsistent with both sections 32 and 34 of the Constitution. The judgment was based on the principle that it did not allow the requester "an adequate and fair opportunity to seek judicial redress after an unsuccessful internal appeal". ${ }^{17}$

It should also be borne in mind that PAJA is in the first instance an Act of general nature. In other words, it prescribes how the powers given to administrators by other laws within a specific area of administration (insolvency legislation) must be exercised. It lays down uniform, system-wide rules about how administrative action authorized by a particular law must be carried out by administrators, and gives members of the public the right to challenge these actions if they do not follow the rules. Any administrative action should therefore comply with the general requirements in PAJA. ${ }^{177}$

It is submitted that the more beneficial view would thus be that special provisions will ordinarily prevail over the more general provision in PAJA,

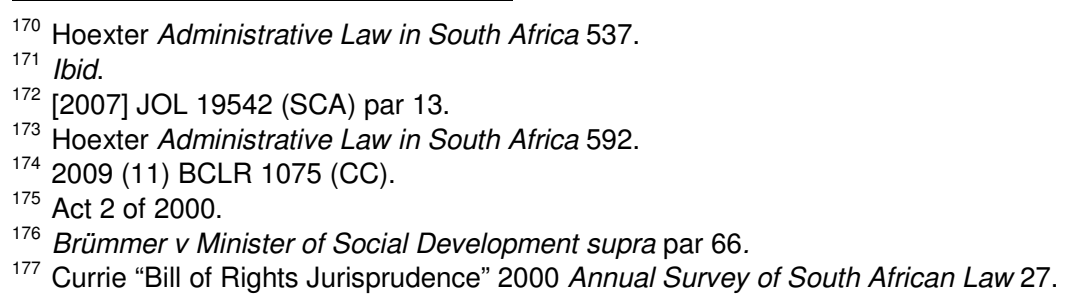


provided of course that they do not unjustifiably infringe on the constitutional rights of the applicant. In Rustenburg Platinum Mines Ltd $v$ Commission for Conciliation, Mediation and Arbitration ${ }^{178}$ Cameron JA stated:

"The Constitution does not require that the legislation enacted to give effect to the right to administrative justice must embody any particular time periods. This is therefore a question on which the legislature may be expected to legislate differently in different fields, taking into account particular needs."

\section{CONCLUSION}

The Constitution, which embodies fundamental human rights, has changed the face of our law dramatically in that legislation may now be tested by the courts in order to establish its constitutionality - the Constitution being the supreme law of the land. In keeping with the salient features of constitutionalism the objective of any state regulation in South Africa should be to conform to the broad philosophical values of the Constitution. Perhaps the most powerful motivation for a dynamic form of administrative justice permeating all types of public power is the determination to avoid any recurrence of instances of oppression and injustices of the past. As the Insolvency Act was in place long before the new constitutional dispensation, it is important that the aim of any law-reform proposal regarding state regulation in insolvency law should be to create an environment of accountability and justification and to bring the regulatory principles of our law in line with the values expressed in modern administrative and constitutional law.

When examining the effect of the Constitution on state regulation in South African insolvency law, it becomes apparent that not a great deal of research, case law or other sources exist on this topic. Despite the lack of any elaborate treatment of the subject, it remains a reality that the Constitution has laid a new foundation in South African law by providing for a multi-faceted right to administrative action. In the context of this discussion the enactment of PAJA is certainly the most relevant and significant constitutional development. As a public body and organ of state the Master is henceforth bound by the provisions of PAJA, with the result that every administrative action performed by the Master is made subject to the requirements for valid administrative conduct and the grounds for review specified therein.

As mentioned earlier, the South African Law Reform Commission is at present in the final stages of introducing a Unified Insolvency Act aimed at modernizing and uniting our insolvency laws. It is submitted that in order to create an effective and efficient regulatory model, policy- and lawmakers should not only recognize contemporary and constitutionally sound insolvency principles in general, but also harmonize the provisions in such legislation with the fundamental principles in the South African administrative law.

\footnotetext{
${ }^{178}$ Rustenburg Platinum Mines Ltd $v$ Commission for Conciliation, Mediation and Arbitration supra.

179 Par 27.
} 
Concern is sometimes raised regarding the impact of the procedural constraints in the Constitution and other relevant legislation applicable to the Master in that these could have the effect of impeding the efficient, effective and swift finalization of an insolvent estate. However, it must be noted that in redefining the role of the law as well as of any public institution, tension will always exist between the procedural fairness and rationality advocated by the Constitution and PAJA, on the one level, and the need for effective, efficient and expeditious public administration, on the other. ${ }^{180}$ The positive challenge therefore lies in absorbing the right to administrative justice entrenched in the Constitution into the development of a regulatory framework with the aim of securing and assuring public confidence in the insolvency process within the current socio-economic circumstances in South Africa.

${ }^{180}$ Corder in Corder (ed) Realising Administrative Justice 18. 